\title{
Social reporting quality determinants: a qualimetric analysis***
}

\author{
Svitlana Bezruchuk ${ }^{1}$, Dmytro Lozynskyi ${ }^{2}$ \\ ${ }^{1,2}$ PhD in Economics, Assistant Professor of the Department of Accounting and Auditing, \\ Zhytomyr Polytechnic State University
}

JEL Classification: $M 41$, C13, C43

\begin{abstract}
The social aspects of business, especially its responsibility, in the modern world are becoming relevant. Particularly important in this regard are the issues of confidence in reporting and its assessment. Today the researches on evaluation of reporting indicators are being conducted in full extent, whereas the problem of what external factors affect the reliability of disclosing indicators in such reports remains open. In the article an approach to the qualimetric analysis of external factors affecting social reporting has been worked out by the authors, namely, factors that influence the formation of reporting indicators have been identified; stages and methods to its assessment by qualimetric analysis have been given; the activity of three large enterprises of Ukraine has been analyzed according to the proposed methods.
\end{abstract}

Keywords: social capital; trust; social networks; social norms; corporate social responsibility; Directive 2014/95/EU.

\section{Introduction}

Business is inseparable from the socio-economic environment of any country, and the vital activity of this environment, in turn, is supported through business. The flows of mutual obligations and responsibilities generated by business, which play a decisive role in shaping the foundation of a company, cause the subjects of this company to have reasonable expectations for business in terms of solving the tasks of social development and environmental safety, reducing the negative consequences of its activities, as well as in optimizing the positive impact on society. A business that recognizes the importance of its contribution to society is considered today as socially responsible.

Social responsibility of business (in the western version - corporate social responsibility - CSR), which is defined as social relations that reflect the level of enterprise obligations in the field of social protection (V. Kushpov, 2005), as a separate area arose in $70 \mathrm{~s}$ and $80 \mathrm{~s}$ in the developed western countries. Several different factors were the reasons for its emergence: the negative attitude of society towards business (violation of the environment, the use of child labor, corruption, etc.), the

Corresponding author:

${ }^{1}$ E-mail address: bezruchuksl@gmail.com

ORCID ID: 0000-0001-7374-7875

${ }^{2}$ E-mail address: dima2005ua@ukr.net

ORCID ID: oooo-0oo1-5368-1530

(C) 2020 S.Bezruchuk, D.Lozynskyi

doi: https://doi.org/10.26642/ppa-2020-1-3-17 
increasing role of the reputation and image of the company as well as brand as a factor in the acquisition of goods and services, and a reduction in government spending in a number of countries in social sphere (for example, the policy of Reagan's new federalism), the emergence of a new element of company value - moral market value.

In recent decades, globalization processes have led to an even greater increase in the participation of companies in areas of a social nature. Today, socially-oriented activities are one of the priorities for business entities in relation to the benefits that it provides, namely the company's emphasis on its social value gives it significant public support. The role of social reporting comes to the first place from the perspective of businesses. It is admired by users, but whether such reports are actually of good quality? How to evaluate what is not measurable? The relevance of these issues is evidenced by facts such as: violation of international human rights and labor standards by employers; non-observance of statutory social and labor rights of employees of enterprises; low wages; prolonged salary arrears; unjustified savings on investment in health and safety of employees (twice less than required by law), as well as on professional education (less than UAH 4 per employee per month).

It does not ignore such an important area as accounting, where corporate relations become a significant segment. «Social responsibility must be reflected in the accounting system»- the scientists proclaim. And, since non-financial reporting is an instrument of corporate social responsibility, the issues of developing a mechanism for the compliance of corporate reporting with the requirements of the social economy became important in this context: the principles, requirements, approaches and provisions according to which reporting should be formed, the relevant forms and their elements should be implemented. A separate important object of accounting is the additional costs associated with solving social issues. As a rule, the most often the ability to reflect them in the reports is decided.

In modern conditions of business activity the information is the most valuable resource for the implementation of the management process, because it is always associated with the implementation of all management functions, such as planning, organization, motivation and control.

The growing role of information in modern conditions, both at the level of individual enterprises and at the level of the world economy, is associated with many factors, among which are the following: expansion of globalization processes, an increase in the speed of data transfer, a growth of the intellectual capital role, growing competition and increased requirements of products (goods, works, services) by consumers. Since the vast majority of the necessary information is accounting information, the requirements for it have grown, especially in terms of the timeliness of its presentation and usefulness to investors.

It is well known that accounting is the basis of information support in the enterprise. Its main task is to provide both internal and external users with information about the financial condition and activities of the enterprise, on the basis of which management decisions are made. The role of the accountant in the process of preparing the decision lies in the timely provision of necessary information to the managerial staff, since it is the accounting service that is one of the leading divisions of the enterprise, which generates information on the results of activity and the property status of the enterprise. Information should be not only complete and reliable, but also in general qualitative. Modern accounting should be qualitatively better than the traditional (classical), however, to establish the criteria for its assessment is not an easy task.

\section{Literature review}

On the pages of scientific journals quite often the thesis that business should be socially responsible is repeated. The breakthrough in the study of social significance came after significant social legislation in the early 1970s. The relevance became established after the adoption in 2002 the Sarbanes-Oxley Act (SOX) as a result of a series of scandals with the reporting of large companies such as Enron and WorldCom, in the USA.

The adoption of strict requirements for financial statements, the actions of managers, directors and auditors, the introduction of criminal penalties for misleading investors helped to survive the crisis and restore investor confidence in financial statements in the United States. The most famous researchers of the social responsibility issues of business are F.Kotler and N.Lee. The authors consider ways to integrate charitable social programs into corporate identity on condition they maximize the benefits for the entire company.

Various issues of social responsibility (value-oriented management models, the impact of corporate social responsibility on investor decision-making, consumer reactions to brands related to social issues and many others) are reflected in the works of J.Weber, E.Mackay, T.Mackay, J.Barney, S.Norik, G.Sarah. Esen E. (2013) examines the influence of corporate social responsibility (CSR) activities on building corporate reputation. The issues of the qualitative characteristics of financial statements were first raised by Hendriksen, M.F. Van Breda, M.Matthews, M.Perera, B.Needles.

Most often, accounting information quality issues are resolved in the context of ensuring the reliability of financial statements, the reliability of accounting data or general requirements for financial statements and the principles of its preparation.

In addition to scientific research, separate international programs or parts of them are devoted to the issue of corporate social responsibility, in particular: UN Development Program «UNDP», Innovation and Development Center programs supported by the Charles Stewart Mott Foundation, Ukrainian project «We invest in social care», Union «Socially responsible business», Ukrainian charity forum, Corporate social responsibility development center, which mission is to introduce systemic changes for the development of social responsibility in Ukraine.

The preparation of the non-financial report is governed by Directive 2014/95/EU of the European Parliament and of the Council of 22 October 2014, the requirements of which state that:

Directive 2014/95/EU: When preparing a non-financial report by an enterprise, it should include the following elements: environmental aspect, details of current and projected environmental impact of the enterprise, as well as health and safety, the use of renewable and/or non-renewable energy sources, greenhouse gas emissions, water consumption and air pollution. 
The Directive caused a lot of discussion among scientists who stressed the need to study the quality of reporting: G.Mion, C.R.L. Adaui (2019), some studies have analyzed particular industrial sectors, particular a cross country analysis (A.Venturelli, F.Caputo, R.Leopizzi, S.Pizzi, 2019). The authors explore how the key features from IC and integrated reporting can be combined to develop an extended model for companies to comply with EU Directive 2014/95/EU and increase trust in corporate disclosures and reports (J.Dumay, M. La Torre, F.Farneti, 2019).

The disclosure of non-financial information by stock-exchange-listed companies in Poland, in the light of the changes introduced by the Directive 2014/95/EU, has been shown by A.Szadziewska, E.Spigarska, E.Majerowska (2018). Content analysis was used in the research, taking into account, while coding the information, its importance for the assessment of a company's environmental and social efficiency. Based on a formulated econometric model, the impact of such factors as the company's size, profitability, the company's market value as well as the industry type on the level of the non-financial disclosures made, has been analyzed.

The evaluation of accounting information quality in Ukraine was analyzed by T.F. Plakhtii (Plakhtii, 2017). This research attempts to determine the methodology for evaluating the quality of financial statements. However, there is not a single study aimed at what factors affect the quality of reporting. Based on the analysis of T.F. Plakhtii a methodology for analyzing the quality of reporting based on influencing factors has been developed.

\section{The identification of previously unresolved issues and the formulation of research hypotheses}

In our opinion, the first step in solving the issues of the qualitative characteristics of information is to determine the factors that affect the quality of accounting information.

Information quality is signs that make the information useful (suitable) to achieve the user's goals.

The quality of accounting resultant information, we understand as the complex of objective properties of information that determine its suitability to satisfy the end users' needs.

There are many diverse properties of information. Information and its properties is the object of study of a number of scientific disciplines, each of which considers those properties that are most important to it. There are various approaches, both to the study of the quantitative and qualitative aspects of information (probabilistic-statistical, combinatorial, algorithmic, semantic, pragmatic, etc.), and to the study of the essence of information as an economic category, the analysis of the cost aspects of its reproduction. From the point of view of accounting, the most important, according to scientists, are the following properties of information: objectivity, completeness, reliability, adequacy, accessibility and relevance.

A lot of information is accumulated in the accounting system, but this does not mean that all of it will be useful for management, since the amount of information does not always mean its quality. However, the formation of information without creating the right conditions to ensure its high quality characteristics leads to the incorrect decision-making. Incorrect or untimely provision of information can cause negative consequences for the enterprise, such as losses and even bankruptcy.

Mion G., Adaui C.R.L. (2019): "The quality of sustainability reporting is much discussed in the literature because this quality affects factors such as the credibility of accountability and building stakeholders' trust in the company. Nonetheless, the concept of quality is multidimensional, and empirical evidence relating to the quality of sustainability reporting presents different findings».

The qualitative characteristics of accounting information include:

1) clarity and comprehensibility, relevance, reliability and comparability according to NP(S)A 1 «General requirements for financial reporting»;

2) the information should be relevant, material, truthful, comparable, timely and understandable according to the Conceptual Framework for Financial Statements.

As we can see, according to the current rules, only information that can affect the user's decision is qualitative. That is, the main qualitative characteristic of accounting information is its value. In addition to the value of information, there are other characteristics that are no less important and provide a high level of information and, as a result, the effectiveness of managerial decisions. In fact, there are many more such characteristics, therefore, first of all, factors affecting the quality of information should be considered. At the second stage, a quantitative assessment of the qualitative characteristics of social reporting should be provided.

The results of this study determined the prospects for further research: to analyze the social reporting of enterprises in order to determine their qualitative characteristics, which will be the basis for the development of methods for assessing the quality of social reporting.

\section{Research methodology and methods}

The authors used scientific methods: systematization, comparison, generalization, analysis, synthesis. The research information base consists of articles by Ukrainian and foreign scientists, materials of international organizations.

The assessment of the quality of social reporting was carried out on the basis of qualimetric analysis, the subject of study of which is the quantitative assessment of product quality, and the measurement result is the level of product quality. Based on this analysis, we tried to quantify the qualitative characteristics of social reporting, primarily by highlighting the factors (or criteria) that directly affect the quality of such reporting.

The study focuses on the activities of large Ukrainian enterprises that publish non-financial statements (PJSC «Obolon», Coca-Cola HBC, PJSC «Mironivsky Hliboproduct»). 
Taking the above into consideration, to obtain answers to the research questions posed, a content analysis scorecard, i.e., a modified version of the content analysis developed by A.Szadziewska, E.Spigarska, E.Majerowska (2018, p. 79-80), was used to disclose environmental information.

\section{Main results}

The qualimetric model uses the principle that factors are distributed as a set of quality properties for its decomposition into components of the first, second, third level, etc. Each factor is measured by the weighting factor of the property index - Mi. In our case, each factor and criterion has its own weight within a unit. We determine the following factors affecting the quality of accounting information: legislative regulation, legal norms, standards and the degree of application of professional judgment, the process of formation and provision, sources of provision, subject of provision, users of information (or end users). In the article, we will consider the assessment of the measurement of factors affecting the quality of the presented social reporting.

Below the summarized factors are given to bring them to qualimetric analysis (Table 1).

Table 1

$\underline{\text { Search factors affecting financial statements }}$

\begin{tabular}{ccc}
\hline Category & Index & $\begin{array}{c}\text { Categories of } \\
\text { assessment }\end{array}$ \\
\hline
\end{tabular}

Political situation and level of legislative regulation $\mathrm{A}$

\begin{tabular}{|c|c|c|c|}
\hline \multirow{4}{*}{ A1 } & \multirow{4}{*}{ The state of the political system } & \multirow{2}{*}{$\begin{array}{l}\text { 1. Is there a strict regulatory framework } \\
\text { for reporting? }\end{array}$} & 0 \\
\hline & & & 1 \\
\hline & & \multirow{2}{*}{$\begin{array}{l}\text { 2. To what extent do reporting entities } \\
\text { depend on the political situation? }\end{array}$} & 0 \\
\hline & & & 1 \\
\hline \multirow{4}{*}{ A2 } & \multirow{4}{*}{$\begin{array}{l}\text { The complex of interactions between its } \\
\text { subjects over a period of time }\end{array}$} & \multirow{2}{*}{$\begin{array}{l}\text { 1. Does the reporting entity depend on } \\
\text { other entities? }\end{array}$} & 0 \\
\hline & & & 1 \\
\hline & & \multirow{2}{*}{$\begin{array}{l}\text { 2. Does the reporting entity depend on the } \\
\text { state? }\end{array}$} & 0 \\
\hline & & & 1 \\
\hline \multirow{8}{*}{$\mathrm{A} 3$} & \multirow{8}{*}{ The degree of legislative regulation } & \multirow{2}{*}{$\begin{array}{l}\text { 1. Is the regulatory framework strong in } \\
\text { the reporting country? }\end{array}$} & 0 \\
\hline & & & 1 \\
\hline & & \multirow{2}{*}{$\begin{array}{l}\text { 2. Are there serious penalties for } \\
\text { misrepresentation in reporting or for } \\
\text { manipulating facts and data? }\end{array}$} & 0 \\
\hline & & & 1 \\
\hline & & \multirow{2}{*}{$\begin{array}{l}\text { 3. Have professional ethics been } \\
\text { developed? }\end{array}$} & 0 \\
\hline & & & 1 \\
\hline & & \multirow{2}{*}{$\begin{array}{l}\text { 4. Are entities required to submit social } \\
\text { reports? }\end{array}$} & 0 \\
\hline & & & 1 \\
\hline \multirow{4}{*}{ A4 } & \multirow{2}{*}{ Application of legal norms and standards } & \multirow{2}{*}{$\begin{array}{l}\text { 1. Reporting methodology that has been } \\
\text { applied }\end{array}$} & 0 \\
\hline & & & 1 \\
\hline & & \multirow{2}{*}{$\begin{array}{l}\text { 2. How rigid is the level of regulation of } \\
\text { the basic principles and rules of drafting }\end{array}$} & 0 \\
\hline & & & 1 \\
\hline \multirow{8}{*}{ A5 } & \multirow{2}{*}{$\begin{array}{l}\text { The degree of application of professional } \\
\text { judgment }\end{array}$} & \multirow{2}{*}{$\begin{array}{l}\text { 1. What information is disclosed in the } \\
\text { reporting? }\end{array}$} & 0 \\
\hline & & & 1 \\
\hline & & \multirow{2}{*}{$\begin{array}{l}\text { 2. Does the information contain general } \\
\text { facts and figures that are independent of } \\
\text { professional judgment? }\end{array}$} & 0 \\
\hline & & & 1 \\
\hline & & \multirow{2}{*}{$\begin{array}{l}\text { 3. The degree of impartiality of the } \\
\text { accounting entities? }\end{array}$} & 0 \\
\hline & & & 1 \\
\hline & & \multirow{2}{*}{$\begin{array}{l}\text { 4. What is the measure of professional } \\
\text { judgment? }\end{array}$} & 0 \\
\hline & & & 1 \\
\hline
\end{tabular}




\begin{tabular}{|c|c|c|c|}
\hline & & & End of table 1 \\
\hline \multicolumn{4}{|c|}{ Source of information submission B } \\
\hline \multirow{5}{*}{ B1 } & \multirow{4}{*}{$\begin{array}{c}\text { The process of forming and submitting } \\
\text { information }\end{array}$} & \multirow{2}{*}{$\begin{array}{l}\text { 1. How big is the gap between the timing } \\
\text { of events and how they are reflected in } \\
\text { documents? }\end{array}$} & 0 \\
\hline & & & 1 \\
\hline & & \multirow{2}{*}{$\begin{array}{l}\text { 2. Is information generated from } \\
\text { independent sources? }\end{array}$} & 0 \\
\hline & & & 1 \\
\hline & Category & Index & $\begin{array}{c}\text { Categories of } \\
\text { assessment }\end{array}$ \\
\hline \multirow{8}{*}{ B2 } & \multirow{8}{*}{ Source of information submission } & \multirow{2}{*}{$\begin{array}{l}\text { 1. Are current technologies used in } \\
\text { reporting? }\end{array}$} & 0 \\
\hline & & & 1 \\
\hline & & \multirow{2}{*}{$\begin{array}{l}\text { 2. What is the quality of the supporting } \\
\text { documents? }\end{array}$} & 0 \\
\hline & & & 1 \\
\hline & & \multirow{2}{*}{ 3. Are current forms of documents used? } & 0 \\
\hline & & & 1 \\
\hline & & \multirow{2}{*}{ 4. Is there proper control? } & 0 \\
\hline & & & 1 \\
\hline & Subject of it & ormation presentation $\mathrm{C}$ & \\
\hline \multirow{8}{*}{$\mathrm{C} 1$} & \multirow{8}{*}{ Information provider characteristics } & \multirow{2}{*}{$\begin{array}{l}\text { 1. Degree of possession of information } \\
\text { about the enterprise }\end{array}$} & 0 \\
\hline & & & 1 \\
\hline & & \multirow{2}{*}{ 2. Knowledge of the law } & 0 \\
\hline & & & 1 \\
\hline & & \multirow{2}{*}{ 3. Degree of ethics compliance } & 0 \\
\hline & & & 1 \\
\hline & & 4. Whether there is proper control over the & 0 \\
\hline & & subject of the submission of information? & 1 \\
\hline \multirow{4}{*}{$\mathrm{C} 2$} & \multirow{4}{*}{$\begin{array}{c}\text { Principles and standards of behavior in } \\
\text { difficult situations }\end{array}$} & \multirow{2}{*}{$\begin{array}{c}\text { 1. Does the company have developed } \\
\text { standards of professional behavior and } \\
\text { ethics? }\end{array}$} & 0 \\
\hline & & & 1 \\
\hline & & \multirow{2}{*}{$\begin{array}{l}\text { 2. How often have the rules been violated } \\
\text { at the enterprise? }\end{array}$} & 0 \\
\hline & & & 1 \\
\hline \multirow{6}{*}{$\mathrm{C} 3$} & \multirow{6}{*}{$\begin{array}{l}\text { Assessing the subject's situation in terms of } \\
\text { the impact of the information }\end{array}$} & \multirow{2}{*}{$\begin{array}{c}\text { 1. For what type of entity is the } \\
\text { information provided (large, medium, } \\
\text { small)? }\end{array}$} & 0 \\
\hline & & & 1 \\
\hline & & \multirow{2}{*}{$\begin{array}{l}\text { 2. Will the information affect the subject's } \\
\text { activity? }\end{array}$} & 0 \\
\hline & & & 1 \\
\hline & & \multirow{2}{*}{$\begin{array}{l}\text { 3. Will information increase public } \\
\text { confidence in the subject of its } \\
\text { submission? }\end{array}$} & 0 \\
\hline & & & 1 \\
\hline \multicolumn{4}{|c|}{ Users of information D } \\
\hline & & 1. Are there user requirements for & 0 \\
\hline & & completeness of information? & 1 \\
\hline & & 2. Are there user requirements for quality & 0 \\
\hline D1 & User characteristics & information? & 1 \\
\hline Di & User cnaracteristics & 3. Are there explanations for the & 0 \\
\hline & & information? & 1 \\
\hline & & 4. Do users have sufficient knowledge? & $\begin{array}{ll}0 \\
1\end{array}$ \\
\hline
\end{tabular}

Source: on the basis of: Szadziewska A., Spigarska E., Majerowska E. (2018, p. 79-80), Plakhtii (2017, p. 284-286)

The general formula of the integrated indicator for assessing the quality of reporting through factors influencing it may be represented as follows:

$\mathrm{IIAQF}=\mathrm{mA}+\mathrm{mB}+\mathrm{mC}+\mathrm{mD}$

where IIAQF - an integrated indicator of assessing the quality of reporting through factors influencing it;

$\mathrm{mA}$ - coefficient of dependence on the political situation;

$\mathrm{mB}$ - source dependency coefficient; 
$\mathrm{mC}$ - the dependency coefficient of the subject;

$\mathrm{mD}$ - coefficient of suitability of the information needs of the user.

The reference value for assessing the quality of reporting by an integral indicator should be equal to one, therefore, reference values of the coefficients of dependence on the weight values of individual coefficients in assessing the quality of reporting should be determined.

It should be noted that the weight values depend on the subjective opinion, but below is the rationale for each component.

The ratio of indicators is as follows (Fig. 1).

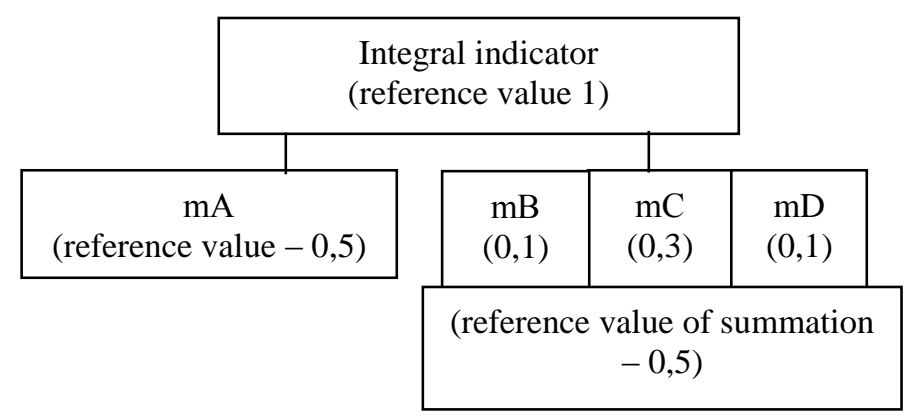

Fig. 1. The weighted value of the coefficients of the integral indicator

Two constituents of $\mathrm{mA}$ are the coefficient of dependence on the political situation and the other three coefficients of $\mathrm{mC}-$ the dependency coefficient of the subject, which should have the highest specific value. The least significant are the $\mathrm{mB}-$ source dependency coefficient and the $\mathrm{mD}$ - coefficient of suitability of the information needs of the user, but such indicators should not be underestimated.

Political situation and degree of legislative regulation (determinant defined as A).

Directive 2014/95/EU on non-financial reporting sets out in the first place the requirement to describe «the policies, results and risks associated with these matters and to be included in the management report of that entity».

It is shown by factors such as: the state of the political system (A1); the complex of interactions between its subjects over a period of time (A2); the degree of legislative regulation (A3); application of legal norms and standards (A4); the degree of application of professional judgment (A5).

It is known that, first of all, the quality of accounting information depends on the methodology used for its formation, as well as on the level of regulation of the basic principles and rules of compilation.

Regulatory documents disclose information requirements. The Law of Ukraine «On Accounting and Financial Reporting in Ukraine» (Article 4) defines the basic principles of accounting and reporting: prudence, full disclosure, autonomy, consistency, going concern, matching principle, the prevalence of essence over form, historical (actual) cost, monetary unit principle, specific time period assumption. Scientists basically define the same requirements for the quality of accounting information.

Qualitative characteristics are also integrated in a certain Art. 3.1 of the Law, the purpose of accounting and financial reporting, in accordance with which it «is to provide users with complete, truthful and unbiased information about the financial condition, results of operations and cash flows of the enterprise for decision-making».

Therefore, the information should be complete, truthful and unbiased. These criteria depend on the possibility and degree of application of professional judgment by an accountant.

Disclosure of material, complete and reliable information in the financial statements, according to which its users will be able to make sound economic decisions, also depends on the way in which the persons who carry out accounting will apply the existing law and the achievements of accounting theory and practice, as well as the possibility of using their professional judgment.

«The recorded is existing - this phrase means the birth in the economic life of the ideal world, the world of accounting data, accounting information, that exists completely separate from the world of real economic life»,- write Ya.V. Sokolov and M.L. Piatov. The illusion of the reliability of accounting data has become a paradox, because accounting information almost never corresponds to the real state of affairs in society. At the stage of accounting inception, this issue was caused by facts that were natural to every household - natural decline, theft, and spoilage. In modern times, it got a purely methodological character, which is associated with the diverging interests of different groups of users, the possibility of applying professional judgment in the compilation of financial statements, taking into account a category such as «significance of accounting information».

For modern accounting, a strong regulatory framework and modern technology is not sufficient. As important as the existing professionalism of the people who keep the records is their ethical position. In this sense, one should not allow the assumptions of the accountant to affect the quality of accounting information. In our opinion, modern legislation has expanded the scope of professional judgment too much.

We suggest to evaluate the political impact factor on the basis of the Doing Business report 2019 «Training for Reform» 16-th edition. Our argument is based on the fact that the greater the investor confidence in the country as a whole, the greater the trust in the social (as in principle and other types of reporting) as a whole (Table 2). 
Table 2

Factors assessment ranking by category «Political situation and level of legislative regulation (A)»

\begin{tabular}{|c|c|c|c|}
\hline Categories & Assessment & $\begin{array}{c}\text { Description of the } \\
\text { assessment }\end{array}$ & Possible values \\
\hline \multicolumn{4}{|c|}{ The state of the political system (A1) } \\
\hline \multirow{2}{*}{ 1. Is there a strict regulatory framework for reporting? } & 0 & absence & \multirow{4}{*}{$\begin{array}{l}\min 0 ; \\
\text { intermediate result } 0,05 \\
\max 0,1\end{array}$} \\
\hline & 1 & strict & \\
\hline \multirow{2}{*}{$\begin{array}{l}\text { 2. To what extent do reporting entities depend on the } \\
\text { political situation? }\end{array}$} & 0 & dependence & \\
\hline & 1 & independence & \\
\hline
\end{tabular}

The complex of interactions between its subjects over a period of time (A2)

\begin{tabular}{llll}
\hline & 0 & dependence \\
\cline { 2 - 3 } 1. Does the reporting entity depend on other entities? & 1 & independence & min $0 ;$ \\
intermediate result 0,05 \\
2. Does the reporting entity depend on the state? & 0 & dependence & max
\end{tabular}

The degree of legislative regulation (A3)

1. Is the regulatory framework strong in the reporting country?

\begin{tabular}{|c|c|c|}
\hline 0 & weak & \multirow{8}{*}{$\begin{array}{l}\min 0 \text {; } \\
\text { intermediate results } 0,03 \text {; } \\
0,05 ; 0,07 \\
\max 0,1\end{array}$} \\
\hline 1 & strong & \\
\hline 0 & missing & \\
\hline 1 & exist & \\
\hline 0 & missing & \\
\hline 1 & designed & \\
\hline 0 & No & \\
\hline 1 & Yes & \\
\hline
\end{tabular}

2. Are there serious penalties for misrepresentation in reporting or for manipulating facts and data?

reporting

3. Have professional ethics been developed?

4. Are entities required to submit social reports?

Application of legal norms and standards (A4)

\begin{tabular}{|c|c|c|c|}
\hline \multirow{2}{*}{ 1. Reporting methodology that has been applied } & 0 & regulated & \multirow{4}{*}{$\begin{array}{l}\min 0 ; \\
\text { intermediate result } 0,05 \\
\max 0,1\end{array}$} \\
\hline & 1 & not regulated & \\
\hline \multirow{2}{*}{$\begin{array}{l}\text { 2. How rigid is the level of regulation of the basic } \\
\text { principles and rules of drafting }\end{array}$} & 0 & regulated & \\
\hline & 1 & not regulated & \\
\hline
\end{tabular}
The degree of application of professional judgment (A5)

\begin{tabular}{lll}
\hline \multirow{2}{*}{ 1. What information is disclosed in the reporting? } & 0 & No \\
\cline { 2 - 3 } & 1 & Yes \\
\hline & 0 & $\begin{array}{l}\text { information } \\
\text { contains general }\end{array}$
\end{tabular}

2. Does the information contain general facts and figures $\quad$ facts and indicators

that are independent of professional judgment?

3. The degree of impartiality of the accounting entities?

Source of information submission $(B)$ is defined by two components: B1 - the process of forming and submitting information and B2 - source of information submission. Assessment of the information quality, first of all, begins with an assessment of the sources of its provision - primary documents, accounting registers and forms of financial and other types of reporting.

Directive 2014/95/EU for non-financial reporting also determines the need for disclosure of due diligence.

Directive 2014/95/EU

"The non-financial report should also include information about the due diligence process implemented at the entity».

To ensure the validity of information, it is necessary to ensure the correctness of its accumulation, methods of collection, registration. If the information in the source documents does not meet the qualitative characteristics, namely: reliability, 
relevance and timeliness, then in the future the information received will not reflect the proper financial condition, which will affect the implementation of mistaken management decisions and negatively affect the further activities of the enterprise.

It should be remembered that the level of quality of information depends both on the quality of the media of primary, current and final information, and on how much it is possible to reduce the gap between the timing of events and their reflection in accounting documents.

This is facilitated by the rational organization of accounting, which ideally should ensure the timeliness, reliability and, in general, the quality of accounting information. For the rapid flow of information at most enterprises, a workflow schedule has been approved. However, often, the quality of information is reduced by the presence of outdated standard forms of source documents, therefore, to avoid such situations, the accountant must monitor changes in legislation and introduce new or update existing forms of source documents.

Thus, the assessment of the quality of accounting information depends on the process of preparing information, the appropriateness of its use and evaluation of the final result. The application of the main qualitative characteristics of accounting information provides the preparation of financial statements, which gives a reliable idea of the financial condition and results of the enterprise, also improves the quality and scope of accounting information in the process of making management decisions. However, the presence of all the listed qualitative characteristics to a sufficient extent does not always ensure the efficient use of information in the enterprise, since, in the absence of proper control information indicators can be changed easily.

The global principles of management accounting, developed by Chartered Global Management Accountant (CGMA, 2015), which most fully characterizes these approaches, are used to build the model. Ranking of factor assessment by category «Source of information submission» is given in Table 3, the weight part of 0,1 .

Table 3

Factors assessment ranking by category «Source of information submission (B)»

\begin{tabular}{|c|c|c|c|}
\hline Categories & Assessment & $\begin{array}{c}\text { Description of the } \\
\text { assessment }\end{array}$ & Possible values \\
\hline \multicolumn{4}{|c|}{ The process of forming and submitting information (B1) } \\
\hline \multirow[t]{2}{*}{$\begin{array}{l}\text { 1. How big is the gap between the timing of events and } \\
\text { how they are reflected in documents? }\end{array}$} & 1 & $\begin{array}{c}\text { persons affected by } \\
\text { these processes are } \\
\text { provided with } \\
\text { timely access }\end{array}$ & \multirow{4}{*}{$\begin{array}{l}\min 0 ; \\
\text { intermediate result } 0,025 \\
\max 0,05\end{array}$} \\
\hline & 0 & No & \\
\hline \multirow{2}{*}{ 2. Is information generated from independent sources? } & 0 & Yes & \\
\hline & 1 & No & \\
\hline
\end{tabular}

Source of information submission (B2)

1. Are current technologies used in reporting?

\begin{tabular}{ll}
1 & Yes \\
\hline 0 & No
\end{tabular}

the organization has

access to real-time

2. What is the quality of the supporting documents?

1 financial and
non-financial performance information

3. Are current forms of documents used?

$0 \quad$ No

$\min 0$; intermediate result 0,01 ;

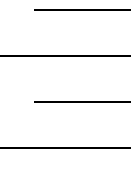

1

Yes
0,$02 ; 0,04$; $\max 0,05$

4. Is there proper control?

stakeholders are informed in a timely manner of violations of the adopted standards

Subject of presentation. Despite the strongest legislative regulation, users of accounting information depend on how correctly accounting concepts in the preparation of financial statements are applied. Consequently, the quality of accounting information is also influenced by the persons who compile and provide this information. Namely, their characteristics such as: the degree of possession of information about the enterprise, knowledge of the current legislation, and the ability to use various 
legal norms (civil, administrative, tax), the ability to use information systems and knowledge in the accounting system. Moreover, not so much professional as personal characteristics of accounting subjects should be put in the first place.

Accounting is not only normative, theoretical and practical principles, but also the ethical standards of persons who deal with it. As B.Needles, H.Andersen, J.Caldwel rightly notice, despite the fact that the responsibility for the preparation of truthful reports lies with the management of the company, «the accountant is also responsible for maintaining ethical standards in the performance of his duties, so as not to be implicated in falsification of reports» [12, p. 119]. Hence, the decisive is the ethics of management personnel, and accountants, as well as auditors.

Of course, the main function of standards and other legislative acts governing accounting is to provide certain information guarantees to users of information, as a result of which the last one must be sure that the accounting system has not gone out of control. They should create a certain system of protection of interests and prevent falsification of statements and distortions of other accounting data. However, no legislation can prevent the inaccuracy of the submitted information and we will never see long-term effective solutions to contest manipulation in accounting, even in the most developed country in the world. That is why, in a complex system of economic activity, there is a huge need to create principles and standards of behavior in difficult situations for individual professional groups. Scientists and practitioners see the need to create these types of principles in the form of ethical codes. These codes should not only be proclaimed by scientists - they must be firmly fixed in accounting and adhered to at the level of practical application.

Particular attention, in our opinion, should be paid to those important aspects that are related to the peculiarity and role of social reports in the activities of enterprises. In the study below, we will try to answer the following questions regarding social responsibility and reporting it:

1. Can a business be socially responsible?

2. How is reporting used in social responsibility?

3. Is it possible to "trust" the reporting data and the information provided with its help by large enterprises?

4. How is the social "burden" of corporations transferred to the shoulders of consumers?

First question: can a business be socially responsible?

The society, represented by its various agents, presents its expectations for each business: to what extent the business can realize them, to the extent it can continue its existence and development.

In other words, a business (and, consequently, an enterprise realizing it and a businessman who organized this enterprise) is responsible to the society in the person of entities experiencing reasonable expectations in relation to this business.

Social responsibility of business is the responsibility of business entities related to compliance with norms and rules that are not explicitly defined or not defined by law (in the field of ethics, ecology, mercy, philanthropy, compassion, etc.) that affect the quality of life of individual social groups and society generally. Hence, a socially responsible business, today, is seen as a business that fully understands the importance of its contribution to solving the social development and environmental safety issues and strives for maximum efficiency, both in reducing the negative consequences of its activities and in optimizing the positive impact to society.

This definition is rather ideal and cannot be fully interpreted into reality, despite the loud statements of most scientists and practitioners that «since the enterprise is a holistic, integrated, evolving and related to the interests of many principals, compliance with the rules of socially responsible business is necessary in relation to all groups of stakeholders» (I.Zhygley, 2010, p. 102).

Firstly, in our opinion, the terms «business» and «social responsibility», based on the essence and etymology of these concepts, are not entirely compatible categories. After all, what is business and what is its role in society? Brightly enough, it can be illustrated by the example of the role of the enterprise as the most stable form of business. Each enterprise is an artificially created system, and like any artificially created system, each enterprise has a goal put down in its basis by the creators, that is, the owners. The role of the enterprise (or firm - these concepts are used as synonyms) is multifaceted, and its essence is multifunctional. According to the views of some economists, the main purpose of the enterprise is to serve as a source of income for owners (shareholders); others believe that the essence of the enterprise is in the production of goods, the satisfaction of the material needs of society; third, speaking of the enterprise, mean its function of providing employment.

But, from whatever position we consider the enterprise, the goal of companies of any form of business, from the point of view of the owner, is very simple to determine - «Make as much money as possible!». Very accurately the goal of the business and the main parameters of this goal were described by Thomas Corbett in the book «TOC's Management Accounting»: «... the goal is to earn more profit now and in the future. Indicators that measure a company's movement toward this goal are Net Profit (NP) and Return on Investment (ROI). These two indicators make it possible to determine where is the company in relation to its goal»».

Business owners take risks by investing their money and much of their time in new companies. And they do this in order to make a profit more significant in comparison with less risky investments. This fully applies to any commercial structures that apply even to areas such as education, or industries such as pharmaceuticals.

Thus, the entire production chain, for example: the production of drugs, their distribution, places of sale - retail and hospital pharmacies, according to the owner, are structures that should be cost-effective, which means they must be profitable, and hardly anyone will argue with this.

The overall goal of the process of improving the enterprise itself and its activities is to create a situation where the relationship between the enterprise and its associated socio-economic and institutional subjects, including the enterprise itself, meets mutual expectations. Of course, the degree of realization of the expectations addressed to the enterprise by other economic and social structures cannot be the same. At different stages of the socio-economic development of society, its 
various subjects present more or less urgent and more or less priority requirements for the enterprise. The subordination and priority of various requirements to the enterprise in the conditions of its independence are determined, on the one hand, by the direct effects of society, and on the other, by the company's own goals.

To engage with stakeholders, companies voluntarily integrate social and environmental aspects into their business. Indeed, in the context of the global globalization and economic crisis, competition in the business environment is aggravating, therefore, an increasing number of manufacturers are forced to look for ways to ensure loyal long-term relationships on the part of customers, employees and other interested parties of the company. From here, there is a reorientation of profitably oriented business to socially responsible.

According to F.Kotler and N.Lee, who analyzed the experience of such well-known companies as Procter \& Gamble, Kraft Foods, Mc Donald's, Nike, Microsoft, etc., the surest path to the consciousness of sophisticated consumers is almost no longer «invulnerable» to traditional product promotion strategies - these are the realization of diverse social initiatives (Kotler and Lee, 2005). The world's leading companies have learned how to make money, changing the world for the better, and with this they gain the favor of hundreds of people, including their customers.

Secondly, social responsibility is not a rule, but an ethical principle. Management of enterprises has a double responsibility to society: legal and social. And if the first is mandatory due to the need to comply with specific laws and regulations that determine what the enterprise can and cannot do, the second is a certain level of voluntary enterprise response to social issues. Once again, it is precisely the voluntary contribution of business to the development of society in the social, economic and environmental spheres that is directly related to the main activity of the enterprise and goes beyond the minimum specified by law.

Liability here is internal, in front of oneself, and is based on moral standards and values acquired in the process of socialization. And if something is not defined at the legislative level, then there are deviations. The deviations, in turn, will occur in accordance with what moral standards and values the owners (possessors) of this business have "acquired".

On this basis, different companies have a different understanding of social responsibility. According to F. Kotler, some companies, for example, believe that if there is any responsibility, then, first of all, to business owners, others believe that social investments help create a good reputation for the company, and therefore services or goods will be sold better. Still others believe that social investment is a fee for the opportunity to do business in a particular country.

An important role in this issue is played by providing consumers with various social reporting. Accordingly, the second important question that should be answered is: how is reporting used in social responsibility?

The essence of accounting is that it is a mechanism for the implementation and interaction of property interests in society. Thanks to this, people get the opportunity to perceive the economic activity of economic entities for a rather long period of time, even if they do not directly participate in it. This is achieved by creating and using information about this activity.

An important tool that informs stakeholders about the company's impact on the sustainable development of society and demonstrates its commitment to the principles of social responsibility is social reporting. The use of social reporting by business entities of Ukraine is considered by scientists and practitioners as an objective necessity.

Non-financial reporting (social reporting, reporting on sustainable development) is a documented set of company data that reflects the environment of its existence, principles and methods of cooperation with influence groups, results of activities in the economic, social and environmental areas of society (M.Shygun, T.Davydyuk, 2011). As defined by the Global Reporting Initiative, the term «sustainability reporting» means reporting that covers at the same time the economic, environmental and social aspects of an enterprise.

A certain part of society is skeptical about the process of preparing reports on sustainable development, which is not regulated by law. Any commercial company or organization has the opportunity to publish sustainable development reports based on GRI, UNGC or other concepts, including reports prepared solely for advertising purposes. The sincerity of such sustainability reports may be in doubt; this is especially true of the reporting of companies engaged in activities that are believed to be harmful to the environment, as well as those commercial entities whose value has fallen significantly as a result of ineffective or unfair management.

Let's make an example. According to the UN Global Compact in Ukraine, which is a voluntary initiative of socially responsible companies, the leading Ukrainian corporation regularly provides information on corporate social responsibility in the form of a social report. The Sustainability Report (Sustainability Report of Obolon PJSC, 2014), available to a wide audience, covers the company's performance in four areas: economic impact, environmental protection and an integrated environmental culture, personnel and working conditions, social investments. This is a company producing low alcohol drinks. It provides social reporting, but can its business be called socially responsible, and the data provided to consumers of reporting is satisfying their needs?

«According to statistics, - the researchers write, - 2/3 of the companies that publish such reports do this for purely economic reasons for shareholders and investors, while others believe that they work for the image. In fact, social reporting addresses the issue of non-financial aspects of business, namely: reputation, customer loyalty, reliability, intellectual capital. However, in the long term, these aspects will influence the financial activities of the company, because its good reputation, reliability and social orientation will significantly accelerate the process of cash investments by returning from all groups of interested parties». That is, accountability, which should become, in fact, one of the principles of socially responsible business and the best tool that informs stakeholders about the company's impact on the sustainable development of society, most often only demonstrates its support for the principles of social responsibility.

From here, a third important question arises: is it possible to «trust» the reporting data and the information provided by large enterprises with its help? 
Firstly, can reporting, even accurately compiled according to the rules prescribed by regulatory documents, be considered reliable? It is completely impossible to do this for the reason that the accounting methodology itself has certain paradoxes. As the famous scientist Ya.V. Sokolov: "You should never believe in the reporting data, they should always be in doubt. Even if during the preparation of the reporting everything was done absolutely correctly, and its compilers had no desire to distort anything, then, nevertheless, analyzing the reporting, we should still be extremely careful about the data that we take into account» (Ya.V. Sokolov, 2006). The paradox is aggravated by the fact that the calculation of profit is very conditional, and the audit report usually confirms the correctness of the accounting procedure, but not its adequacy to the real situation.

As far as non-financial reporting is concerned, today there are a number of authoritative methods that define the concept of «social reporting» and the principles of its compilation. A number of countries (Denmark, Sweden, Norway, the Netherlands, France, the UK) have turned social reporting into an effective public policy tool, requiring large companies to publish their social reports annually. But in most countries, including Ukraine, such reporting is not mandatory.

The fact that the standards are applied voluntarily, and enterprises are free in their choice of reporting criteria, allows companies to disclose only information that is favorable to themselves and to avoid the one that indicates negative dynamics or is considered too delicate to reflect in the reporting. So, one of the most significant issues facing Ukrainian commercial companies is corruption, while the sustainability reports prepared by Ukrainian companies contain very little information about what measures companies are taking in this regard (L.Garbenute, 2010).

Until legislative requirements for the preparation of reports on sustainable development are adopted, there is only one way to overcome the prevailing understanding of corporate responsibility and reporting programs on sustainable development, as pursuing exclusively commercial and advertising goals, namely: Ukrainian commercial companies should start reflecting in their reports those indicators that require improvement, and provide such reports on a regular basis, which will allow to certify willingness and ability of the company to continuous improvement.

However, in our opinion, the issue is not as solvable as it seems at first sight. It is not enough to introduce separate lines or reporting forms in this direction to solve the social accounting issues. The main reason we consider some contradictions, which include the need for social responsibility of the company and the responsibilities of managers. In particular, we have an issue in the consistency of this responsibility with the legal obligations of managers, especially with the obligation to make a profit. «Even the most rigorous members of the public acknowledge that entrepreneurs neglect social responsibility not for their own satisfaction, but for profit» (James A.F. Stoner, Edwin G. Dolan, 2000). A manager cannot afford to replace efficiency with patriotism, because profitability is the main indicator of measuring his performance.

«Not because multinational companies began to massively carry out various industries to less developed countries because they wanted to promote the lasts or were driven by other social motives of the same kind; without denying the best of them a pronounced motive for social responsibility, we will, however, be objective: the same race for efficiency is the main motive» (S.E. Pivovarov, L.S. Tarasevich, A.I. Maizel, 2002, p. 17).

In business environment, corporate social responsibility (CSR) is becoming increasingly an important issue for every stakeholder. Organizations are being reputable through CSR activities (Esen E., 2013, p. 133-50).

To confirm the above, we present a special case where the reflection of social responsibility or its consequences in the reporting conflict with other factors. Unsatisfied with the size of the profit shown in the financial statements, the president of a large company set the task of increasing profit before the executive of one of the subdivisions. The issue was resolved by reducing advertising costs by the end of the quarter. This year, the company will really have big profits, the manager receives his bonus for solving the task, the size of which depends on profitability, but in the long run, in particular, next year, the business will have certain complications. If we consider this situation in the plane of reflection of profit in reporting, the profitability indicator in this case does not guarantee stability and does not characterize social responsibility, because in the future such a policy may lead to a reduction in social payments, and, in the worst cases, the suspending of individual industries, with subsequent the release of staff.

This issue was researched by J.Dumay, M. La Torre, F.Farneti (2019), which determine: although the discrepancy between reporting and organizational behavior persists, increasing, updating, or expanding of disclosed information is not sufficient to build trust with corporations.

That is why, according to J.Dumay, M. La Torre, F.Farneti (2019), managers should abandon agency theory in practice, and specifically the bonus contract.

Of great importance in ensuring the social orientation of accounting is the position of an individual accountant in the enterprise. And, despite the fact that, according to scientists, - «... the accountant must work according to the rules that do not meet the interests of any particular group of people, not, especially, the interests of the owners, but according to the rules drawn up by the society» (I.Zhyglei, 2013, p. 39), this is not possible due to the fact that the accountant, like the manager, is primarily dependent on the chief of the enterprise.

Given the statement of prof. Lou Traas that in many enterprises «the director's report contains absolutely insufficient information on the future strategy of the company» (Lou Traas, 2003, p. 70), the necessary elements of reporting should be a reflection of the current and future strategy of the enterprise, risk factors, trends, in the development of the market situation and technologies, policies, in various fields, including in the field of environmental protection and social expenses.

In this connection, the fourth question arises: how is the social «burden» of corporations transferred to the shoulders of consumers?

The presence of non-financial reporting under certain conditions can increase the capitalization of a company, reduce the cost of a financial resource or extend the term for attracting financial resources. On the other hand, a situation may arise when 
the reflection in the reporting of expenses for social programs will become the subject of various frauds with the aim of artificially increasing the company's reputation.

As noted by prof. Lou Traas, - «in critical situations, when it turns out that some information can have a negative effect, they (companies in the Netherlands - author's note) tend to hide it using the loyalty of the rules in the Netherlands» (Lou Traas, 2003, p. 70).

What can we say about Ukrainian enterprises, the primary task for which, of course, is to manage growth and development, as well as taking measures aimed at overcoming the consequences of the economic crisis! Similarly, we can conclude that if this creates a positive effect, enterprises will try to provide complete (and not always reliable) information.

Ranking of factor assessment by category «Subject of information presentation» is given in Table 4, the weight part of 0,3.

Table 4

Ranking of factor assessment by category «Subject of information presentation (C)»

\begin{tabular}{|c|c|c|c|}
\hline Categories & Assessment & $\begin{array}{c}\text { Description of the } \\
\text { assessment }\end{array}$ & Possible values \\
\hline \multicolumn{4}{|c|}{ Information provider characteristics $(\mathrm{C} 1)$} \\
\hline \multirow[t]{2}{*}{ 1. Degree of possession of information about the enterprise } & 1 & $\begin{array}{l}\text { Information in free } \\
\text { access }\end{array}$ & \multirow{8}{*}{$\begin{array}{l}\min 0 ; \\
\text { intermediate result } \\
0,03 ; 0,05 ; 0,07 ; \\
\max 0,1\end{array}$} \\
\hline & 0 & closed & \\
\hline \multirow[t]{2}{*}{ 2. Knowledge of the law } & 1 & enough & \\
\hline & 0 & insignificant & \\
\hline \multirow[t]{2}{*}{ 3. Degree of ethics compliance } & 0 & persistent violations & \\
\hline & 1 & not violeted & \\
\hline \multirow[t]{2}{*}{$\begin{array}{l}\text { 4. Whether there is proper control over the subject of the } \\
\text { submission of information? }\end{array}$} & 1 & $\begin{array}{c}\text { reliable internal } \\
\text { audit system created }\end{array}$ & \\
\hline & 0 & $\begin{array}{l}\text { there is no system } \\
\text { or it is not reliable }\end{array}$ & \\
\hline \multicolumn{4}{|c|}{ Principles and standards of behavior in difficult situations (C2) } \\
\hline \multirow{2}{*}{$\begin{array}{l}\text { 1. Does the company have developed standards of } \\
\text { professional behavior and ethics? }\end{array}$} & 1 & Yes & \multirow{4}{*}{$\begin{array}{l}\min 0 ; \\
\text { intermediate result } 0,05 \\
\max 0,1\end{array}$} \\
\hline & 0 & No & \\
\hline \multirow{2}{*}{$\begin{array}{l}\text { 2. How often have the rules been violated at the } \\
\text { enterprise? }\end{array}$} & 0 & often & \\
\hline & 1 & $\begin{array}{l}\text { missing or single } \\
\text { cases }\end{array}$ & \\
\hline \multicolumn{4}{|c|}{ Assessing the subject's situation in terms of the impact of the information (C3) } \\
\hline \multirow{2}{*}{$\begin{array}{l}\text { 1. For what type of entity is the information provided } \\
\text { (large, medium, small)? }\end{array}$} & 1 & large & \multirow{6}{*}{$\begin{array}{l}\min 0 ; \\
\text { intermediate } \\
\text { result } 0,025 ; 0,5 \\
\max 0,1\end{array}$} \\
\hline & 0 & medium or small & \\
\hline \multirow[t]{2}{*}{ 2. Will the information affect the subject's activity? } & 0 & Yes & \\
\hline & 1 & No & \\
\hline \multirow{2}{*}{$\begin{array}{l}\text { 3. Will information increase public confidence in the } \\
\text { subject of its submission? }\end{array}$} & 1 & No & \\
\hline & 0 & Yes & \\
\hline
\end{tabular}

Users of information (end users). Information that leaves the accounting system should contribute to the making sound economic decisions, both within the enterprise and its external users. The quality of such information is affected not only by the persons who provide such information, but also by the persons who carry out its verification (auditors, controllers), as well as, directly, users.

As for users, it is they who determine the value and, therefore, the quality of information. It is believed that the most valuable information is useful. It should be considered that biased, inaccurate information (for example, fiction) is of great importance to humans. It would seem that this does not apply to accounting information. However, despite the fact that the quality of information is one of the most important parameters for the consumer of information, we have a certain contradiction that arises between the requirements of users for quality and the requirements of persons who provide information regarding its semantic content. On the one hand, the accounting information should contain the maximum of what is necessary for interested parties (users) to know and contain the necessary explanations. On the other hand, each user, for the most part, is not interested in the accuracy of the information and the integrity of its provision, but in its usefulness, that is, the ability to achieve a certain goal with the least effort.

Accordingly, the quality of accounting information is determined by two aspects. The first aspect is determined by the purpose of using accounting information. For example, the same information will have different values for different managerial purposes. The second is the possibility of using it by interested parties (especially external users). In particular, interested users who need information about a particular enterprise should have sufficient knowledge to understand, evaluate and use such information. In turn, the information provided by them should be operational, since over time the value is lost. 
At each of the selected levels, it is necessary to evaluate the relative importance of single and complex indicators, for which various types of methods based on expert opinions can be used. The sum of the coefficients of significance should be equal to one. The factors and criteria suggested by us are indicative and do not pretend to be final, but this is the experience of using an integrated approach.

Ranking of factor assessment by category «Users of information» is given in Table 5, the weight part of 0,1 .

Table 5

Factors assessment ranking by category «Users of information (D)»

\begin{tabular}{|c|c|c|c|}
\hline Categories & Assessment & $\begin{array}{l}\text { Description of the } \\
\text { assessment }\end{array}$ & Possible values \\
\hline \multicolumn{4}{|c|}{ User characteristics (D1) } \\
\hline \multirow{2}{*}{$\begin{array}{l}\text { 1. Are there user requirements for completeness of } \\
\text { information? }\end{array}$} & 1 & enough & \multirow{8}{*}{$\begin{array}{l}\min 0 \\
\text { intermediate result } \\
0,03 ; 0,05 ; 0,07 ; \\
\max 0,1\end{array}$} \\
\hline & 0 & not enough & \\
\hline \multirow{2}{*}{ 2. Are there user requirements for quality information? } & 1 & enough & \\
\hline & 0 & not enough & \\
\hline \multirow{2}{*}{ 3. Are there explanations for the information? } & 1 & enough & \\
\hline & 0 & not enough & \\
\hline \multirow{2}{*}{ 4. Do users have sufficient knowledge? } & 1 & enough & \\
\hline & 0 & not enough & \\
\hline
\end{tabular}

Table 6

To bring each factor by weight category, we suggest the following evaluation system

\begin{tabular}{cc}
\hline Coefficient level & Weight characteristic \\
\hline 0 & 0 \\
$0,1-0,29$ & 0,1 \\
$0,2-0,39$ & 0,2 \\
$0,4-0,59$ & 0,3 \\
$0,6-0,79$ & 0,4 \\
$0,8-1$ & 0,5 \\
\hline
\end{tabular}

This division is expertly defined and helps to evaluate the impact of each factor in the weight category.

\section{Concluding remarks}

Not only the quality of analytical research, but also the effectiveness of the managerial influence on the objects of management depends on the quality of information support, its completeness, reliability, timeliness, objectivity. The high quality of accounting information will only be ensured by the application of holistic accounting principles (or a single accounting policy) and consideration of all factors that affect the construction of a high-quality information system, including the accounting system. The results of the above methodology will differ significantly: in indicator A - when assessing the activity of enterprises operating in different countries; in indicator B, C - when evaluating the activities of different types of enterprises (large, small, medium). And if for the former one can find an assessment on the Internet, then for small enterprises the assessment is carried out by an expert.

Let's apply the developed methodology for assessing the reporting of large enterprises: PJSC «Obolon» (1) (Sustainability Report of PJSC «Obolon», 2014, 2014), Coca-Cola HBC (2) (Sustainability Report of Coca-Cola HBC in Ukraine, 2018), PJSC «Mironivsky Hliboproduct» (3) (Non-financial report of PJSC «Mironivsky Hliboproduct»). Note that since the studies were conducted within the framework of enterprises in the territory of one state, the indicators A and D in the assessment will be the same (Table 7).

As a conclusion, note that the very concept of «business» and «social responsibility» are incompatible categories. Preparation of social corporate reporting by large companies is mainly used to gain consumer confidence and promote their product, which leads to maximum profit growth. State regulation of social responsibility, as well as an increase in expenses for social purposes and the need to reflect them in reports, as a result, affect the end consumers.

Definitely, any innovations will be entrusted to consumers. Although, the reflection of social expenses and their consideration from the point of view of the legitimacy of referring to the cost of the manufactured product, the services provided may be one of the solutions to the issue. After all, in the end, social expenses allocated to each product, service, type of activity, and included in the cost, will ultimately be paid by the consumer. That is, such actions, on the one hand, enable the company to take part in social projects and be socially responsible, on the other hand, create additional costs, included in the price of the product, for consumers of products whose social rights are somewhat violated in this case. 
Table 7

Research matrix of the assessment of factors of companies

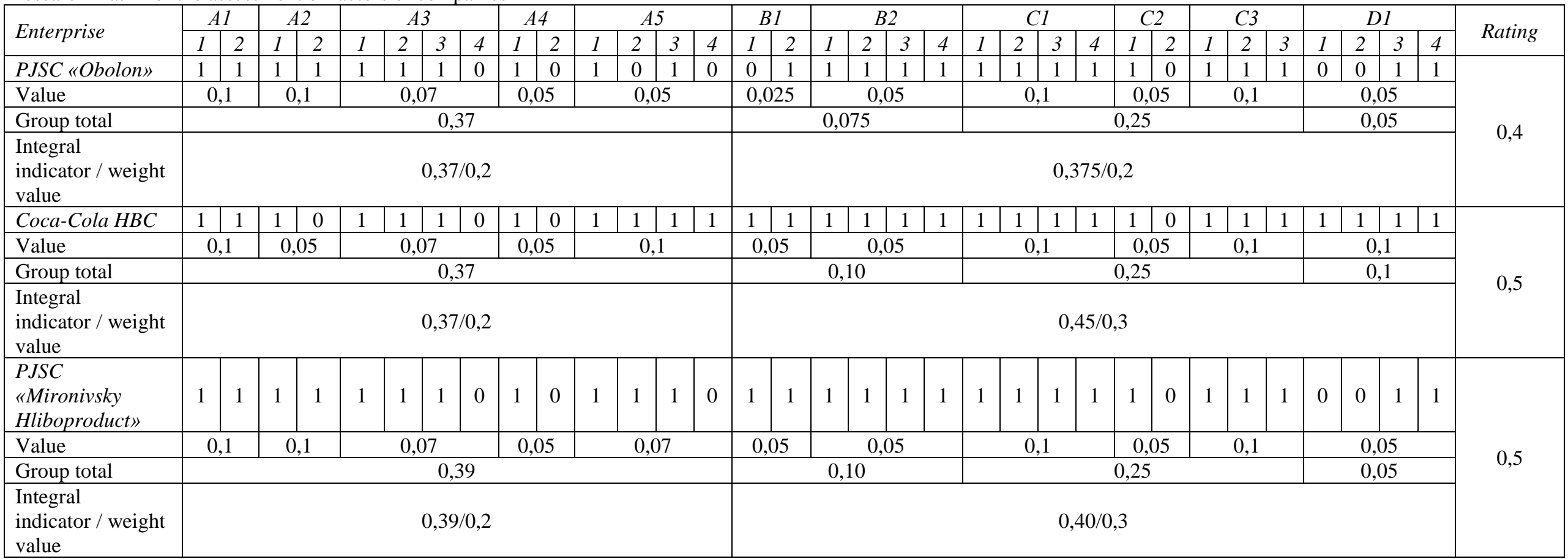

value 


\section{References:}

1. A Word Bank Group Flagship Report (2019), Doing Business 2019, Training for Reform, 16th ed., 311 p, [Online], available at: https://www.doingbusiness.org/content/dam/doingBusiness/media/Annual-Reports/English/DB2019-report_web-version.pdf

2. Verkhovna Rada of Ukraine (2013), Accounting Standards Provisions № 1 "General requirements for financial reporting», [Online], available at: http://zakon1.rada.gov.ua/laws/show/z0336-13

3. Directive 2014/95/UE of the European Parliament and Council from October 22, 2014, changing the Directive 2013/34/EU in reference to reporting non-financial information and information on diversity by some large entities and groups, [Online], available at: http://msfz.ligazakon.ua/ua/magazine_article/FZZ00125

4. Dumay, J., La Torre, M. and Farneti, F. (2019), «Developing trust through stewardship: Implications for intellectual capital, integrated reporting, and the EU Directive 2014/95/EU», Journal of Intellectual Capital, Vol. 20, Issue 1, 14 February, pp. 11-39, [Online], available at: DOI: 10.1108/JIC-06-2018-0097

5. Esen, E. (2013), «The influence of corporate social responsibility (CSR) activities on building corporate reputation», Advances in Sustainability and Environmental Justice, Vol. 11, pp. 133-150.

6. Garbenute, L. (2010), «Korporativnaya sotsial'naya otchetnost' v Ukraine», Ekonomicheskie izvestiya, No. 163 (1396), [Online], available at: http://eizvestia.com/sp_business_finance/full/korporativnaya-socialnaya-otchetnost-v-ukraine

7. Chartered Institute of Management Accountants (2014), Global'ni printsipi upravlins'kogo obliku, Chartered Global Management Accountant, 56 p, [Online], available at: https://www.cgma.org/content/dam/cgma/resources/reports/downloadabledocuments/ukranianfull-gmaps-document.pdf

8. Kotler, F. and Lee, N. (2005), Korporativnaya sotsial'naya otvetstvennost'. Kak sdelat' kak mozhno bol'she dobra dlya vashei kompanii i obshchestva, in Yarinich, S. (ed.), Standart, K., 302 p.

9. Kushpov, V.A. (2005), «Sotsial'naya otvetstvennost' kak faktor razvitiya predpriyatii», Abstract of the diss. ... k.e.n., spec. 08.00.05, Ekonomika i upravlenie narodnym khozyaistvom, Moskva, [Online], available at: http://www.ecsocman.edu.ru/db/msg/202481.html

10. Pivovarova, S.E., Tarasevicha, L.S. and Maizelya, A.I. (ed.) (2002), Mezhdunarodnyi menedzhment, Piter, SPb, 576 p.

11. Mion, G., Adaui, C.R.L. (2019), «Mandatory nonfinancial disclosure and its consequences on the sustainability reporting quality of Italian and German companies», Sustainability, Vol. 11, Issue 17, September 2019, [Online], available at: http://doi.org/10.3390/su11174612

12. Needles, B.E. and others (2004), Principles of Accounting, 2 nd ed., Transl. from Eng. Needles, B.E., Andersen, H.R., Caldwel J.S., in Ya.V. Sokolova (ed.), Finance and Statistics, Moskva, 496 p.

13. Non-financial report of AH Mironivsky Hliboproduct (2017) [Online], available at: http://www.mhp.com.ua/uk/responsibility/stalijrozvitok.

14. Plakhtii, T.F. (2017), Rozvitok teoriï i metodologï bukhgalters'kogo obliku na osnovi yakisnogo pidkhodu, Vid. O.O. Jevenok, Zhitomir, 304 p.

15. Kelenira, D., Svogermana, L. and Ferkh, V. (ed.) (2003), Predvidenie budushchego: besedy s finansovymi strategami, Transl. from Eng., XXVI, INFRA-M, Moskva, 229 p.

16. Pronishin, A. (2010), «Tsel' biznesa s pozitsii sobstvennika», Apteka, No. 760 (39), p. 9, [Online], available at: http://pda.apteka.ua/article/55321

17. Samsonova, K.V. and Buryak, V.O., «Nefinansovaya otchetnost', ee sushchnost' i znachenie v usloviyakh sotsial'no-orientirovannoi ekonomiki», Advanced technologies of science and education, XIV Mizhnarodna naukova internet-konferencija, [Online], available at: http://intkonf.org/samsonova-kv-buryak-vo-nefinansova-zvitnist-yiyi-sutnist-ta-znachennya-v-umovah-sotsialno-orientovanoyi-ekonomiki/

18. Shygun, M.M. and Davydyuk, T.V., (2011), «Korporativnaya sotsial'naya otchetnost' kak perspektiva informirovaniya o chelovecheskom kapitale otechestvennykh kompanii», Visnyk Zaporiz'kogo nacional'nogo universytetu, No. 1 (9), pp.173-178, [Online], available at: http://web.znu.edu.ua/herald/issues/2011/eco_2011_1/2011_1/173-178.pdf

19. Sokolov, Ya.V. and Piatov, M.L., Entertaining essays on the history of accounting, [Online], available at: http://www.buh.ru./document.jsp?ID=51

20. Sokolov, Ya.V., «Paradoksy bukhgalterskoi otchetnosti», Finansy, pravo, menedzhment, [Online], available at: http://www.flm.su/?actions=main_content\&id=285

21. Stoner, James A.F. and Dolan, Edwin G. (2000), Vstuplenie v biznes, Transl. from Eng., in. Zavadskogo, I.S. (ed.), Izd-vo Evrop. un-ta fin., inform. sistem, menedzhmenta i biznesa, K., $752 \mathrm{p}$.

22. Sustainability Report of Coca-Cola HBC in Ukraine (2018), [Online], available at: http://www.cocacolaukraine.com/content/dam/journey/ua/uk/private/2019/July/Coca-Cola-Corporate-Report-GRI-2018.pdf

23. Sustainability Report of Obolon PJSC (2014), [Online], available at: http://obolon.ua/rus/corporate-responsibility/social-reporting/

24. Szadziewska, A., Spigarska E. and Majerowska, E. (2018), «The disclosure of non-financial information by stock-exchange-listed companies in Poland, in the light of the changes introduced by the Directive 2014/95 / EU», Zeszyty Teoretyczne Rachunkowości, Vol. 99 (155), pp. 65-95, [Online], available at: http://ztr.skwp.pl/resources/html/article/details?id=180091

25. Verkhovna Rada Ukraine (1999), On Accounting and Financial Reporting in Ukraine, Zakon 996-XIV vid 16 july 1999 , No. 40, [Online], available at: http://zakon2.rada.gov.ua/laws/show/996-14

26. Venturelli, A., Caputo, F., Leopizzi, R. and Pizzi, S. (2019), «The state of art of corporate social disclosure before the introduction of non-financial reporting directive: a cross country analysis», Social Responsibility Journal, Vol.15 (4), pp. 409-423, [Online], available at: DOI: $10.1108 /$ SRJ-12-2017-0275

27. Zhygley, I.V. (2010), Bukhgalterskii uchet sotsial'no otvetstvennoi deyatel'nosti sub"ektov khozyaistvovaniya: neobkhodimost' $i$ orientiry razvitiya, ZhGTU, Zhitomir, $496 \mathrm{p}$.

28. Zhygley, I.V. (2012), «Strategiya razvitiya predpriyatiya: rol' rukovoditelya ta bukhgalterskoi sluzhby», Nauchnyj vestnik Bukovinskogo gos. fin. -jek. Un-ta, Issue 2 (23), [Online], available at: http://archive.nbuv.gov.ua/portal/soc_gum/Nvbdfa/2012_2/zhyhlei.pdf

${ }^{* *}$ How to cite this article: Bezruchuk S., Lozynskyi D. Social reporting quality determinants: a qualimetric analysis. Public Policy and Accounting. 2020, Vol. 1. https://doi.org/10.26642/ppa-2020-1-3-17 